\title{
DAMPAK KEBERADAAN USAHA PERTAMBANGAN TEMBAGA DI PAPUA TERHADAP PEREKONOMIAN NASIONAL: ANALISIS INPUT-OUTPUT
}

\author{
Impact of the Existence of Copper Mining in Papua on the National \\ Economy: Input-Output Analysis
}

\author{
RIDWAN SALEH dan TRISWAN SUSENO \\ Puslitbang Teknologi Mineral dan Batubara \\ Jalan Jenderal Sudirman 623 Bandung 40211 \\ Telp. (022) 6030483, Fax. (022) 6003373 \\ e-mail: ridwans@tekmira.esdm.go.id
}

\begin{abstract}
ABSTRAK
Sektor Pertambangan tembaga di Papua telah memberikan kontribusi terhadap pembentukan Produk Domestik Bruto (PDB) nasional, baik secara langsung maupun tidak langsung. Pengganda output ke arah belakang sebesar 1,524, artinya bahwa setiap satu juta rupiah nilai penjualan tembaga berkontribusi menambah output perekonomian nasional menjadi 1,524 juta rupiah. Komposisinya terdiri dari satu juta rupiah nilai penjualan tembaga itu sendiri, 0,263 juta rupiah dampak tidak langsung karena mekanisme rantai pasokan dan 0,262 juta rupiah dampak tidak langsung dari belanja rumah tangga yang sumber pendapatannya berasal dari Sektor Pertambangan Tembaga. Angka pengganda output ke arah depan sebesar 1,871 artinya bahwa setiap satu juta rupiah nilai penjualan tembaga, dapat mendorong penciptaan output nasional sebesar 1,871 juta rupiah. Komposisinya terdiri dari 0,762 juta rupiah penambahan output di sektor lapangan usaha lain akibat adanya mekanisme supply-chain, dan 0,109 juta rupiah tambahan output di sektor-sektor lainnya akibat peningkatan belanja rumah tangga, yang sumber pendapatannya berasal dari Sektor Pertambangan Tembaga. Sektor Pertambangan Tembaga memiliki angka dampak pendapatan sebesar 1,753 artinya bahwa setiap satu juta rupiah pendapatan pekerja di sektor pertambangan, akan meningkatkan pendapatan seluruh pekerja secara nasional menjadi sebesar 1,753 juta rupiah. Komposisinya terdiri dari satu juta rupiah diterima oleh pekerja di sektor pertambangan, 0,364 juta rupiah diterima oleh pekerja di sektor lainnya akibat mekanisme keterkaitan intraindustri, dan 0,389 juta rupiah pendapatan pekerja di sektor lainnya akibat mekanisme induksi pendapatan.
\end{abstract}

Kata kunci : sektor pertambangan tembaga, pengganda, output, pendapatan, tenaga kerja.

\begin{abstract}
The copper mining sector has contributed to the formation of national Gross Domestic Product (GDP), either directly or through an indirect mechanism. Output multiplier of backward linkages of 1.524, it means that every IDR one million rupiah value of copper sales contribute to increase the output of the national economy into IDR 1,524 million, which is composed of IDR one million is the value of sales of copper itself, IDR 0.263 indirect impacts due to the mechanism of the supply chain and IDR 0.262 million is the indirect impact of household spending, which is the source of income comes from copper mining sector. The output multiplier from the forward linkages of 1.871 means that every one million sales value of copper, may encourage the creation of national output amounted to IDR 1.871 million, which is composed of IDR 0.762 million is the addition of output in the other business sectors due to the mechanism of supply-chain and IDR 0.109 million additional output in other sectors due to the increase in household spending, which is the source of income comes from copper mining sector. The copper mining sector has numbers impact revenues of 1.753 meaning that every one million rupiah income of workers in the mining sector, will increase the income of all workers nationwide
\end{abstract}


amounted to IDR 1,753 million, which is composed of one million received by workers in the mining sector, IDR 0.364 million received by workers in other sectors due to the mechanism of intra-industry linkages, and IDR 0.389 million the income of workers in other sectors due to the mechanism of revenue induction.

Keywords: copper mining sector, multiplier, output, income, employment

\section{PENDAHULUAN}

Perusahaan pertambangan yang menghasilkan konsentrat tembaga dalam perannya sebagai penghasil utama penerimaan negara dan devisa dituntut untuk meningkatkan perannya dalam membangun perekonomian nasional sehingga dapat memberikan dampak pertumbuhan ekonomi yang positif bagi Indonesia (Weya, Naukoko dan Kawung, 2015).

Sektor usaha pertambangan tembaga di Indonesia saat ini didominasi oleh dua perusahaan yaitu PT Newmont di Provinsi Nusa Tenggara dan PT. Freeport Indonesia di Papua. Tulisan ini hanya mengkaji dampak usaha pertambangan tembaga di Papua terhadap perekonomian nasional.

Dampak ekonomi adalah pengaruh terhadap aktifitas perekonomian pada suatu daerah (Sumardjoko, 2013) atau nasional akibat hadirnya suatu aktifitas program atau proyek. Dampak ekonomi dapat dilihat pada: (1) output bisnis (volume penjualan), (2) nilai tambah ekonomi (atau produk domestik bruto/PDB), (3) pendapatan individu (mencakup upah), dan (4) kesempatan kerja. Setiap indikator tersebut dapat menjadi suatu indikator kemajuan kesejahteraan ekonomi dari penduduk atau masyarakat, dimana indikator tersebut merupakan sasaran pembangunan ekonomi (Weisbrod, 2017).

Analisis dampak ekonomi berusaha menelusuri pengaruh aliran belanja uang dari suatu aktifitas program atau proyek terhadap perubahan output, pendapatan pekerja, lapangan kerja (job creation) yang muncul di suatu wilayah analisis. Dampak ekonomi difokuskan pada penyebaran pengaruh ke seluruh aktifitas perekonomian dan hanya mengukur nilai arus uang dari transaksi pasar. Dampak ekonomi bersih biasanya dilihat dari pengembangan (expansion) atau pengerutan (contraction) dari perekonomian daerah sebagai hasil dari proyek atau program. Dampak bersih tersebut dapat berasal dari proyek yang sudah ada (existing) atau dari proyek baru. Dampak ekonomi biasanya dilihat dari kesempatan kerja, pendapatan dan atau penjualan bisnis yang langsung atau tidak langsung terpengaruh oleh proyek.

Beberapa ukuran dampak ekonomi yang akan digunakan dalam kajian dampak ekonomi terhadap keberadaan sektor pertambangan tembaga di Indonesia adalah:

1. Lapangan pekerjaan atau kesempatan kerja (employment). Indikator ini menggambarkan penambahan pekerjaan yang tercipta oleh pertumbuhan ekonomi.

2. Pendapatan agregat penduduk (aggregate personal income), diakibatkan oleh kenaikan tingkat upah/gaji dan atau kenaikan jumlah orang yang bekerja. Kedua kondisi tersebut muncul sebagai hasil dari pertambahan penerimaan usaha atau bisnis.

3. Nilai tambah bruto (gross value added/GVA), besaran ini adalah ekuivalen dengan PDB dan perluasan ukuran dari dampak pendapatan agregat penduduk.

4. Output usaha (business output) adalah penerimaan usaha kotor atau nilai penjualan dari kegiatan memproduksi barang/jasa. Sebagian penerimaan kotor dipakai untuk membayar biaya-biaya material/jasa dan tenaga kerja serta menyisakan pendapatan usaha atau profit. Value added adalah fraksi tertentu dari output usaha, sehingga angkanya pasti lebih kecil daripada output usaha.

Stimulus yang digunakan untuk menghitung dampak makro dari kehadiran perusahaan pertambangan tembaga di Indonesia adalah nilai penjualan produk tambang dari perusahaan penghasil, baik yang dijual secara ekspor dalam bentuk konsentrat, maupun yang dijual ke lokasi lain di dalam negeri untuk dilebur menjadi katoda tembaga dan produk samping lainnya. Hasil dari stimulasi nilai penjualan tersebut akan menghasilkan dampak ekonomi secara moneter dalam bentuk nilai output, nilai tambah bruto, dan pendapatan rumah tangga. Stimulus lain yang digunakan dalam analisis kajian ini adalah tenaga kerja yang diperkerjakan langsung oleh sektor 
pertambangan tembaga, baik sebagai tenaga produksi di tambang maupun bukan produksi yang berlokasi di Kabupaten Mimika serta karyawan di kantor-kantor perwakilan dalam negeri.

\section{METODE}

\section{Metode Pengumpulan dan Pengolahan Data}

Data yang diperlukan dalam kegiatan penelitian ini dibagi menjadi dua bagian, yaitu data primer dan sekunder. Data primer diperoleh secara langsung dengan metode wawancara ke perusahaan tembaga, sedangkan data sekunder didapatkan dari berbagai sumber dalam bentuk laporan, baik yang telah dipublikasikan maupun yang tidak dipublikasikan.

Data utama yang diperlukan untuk menghitung dampak ekonomi dari perusahaan ini adalah Tabel Input-Output Indonesia Tahun 2010 berukuran 52 X 52 sektor yang disusun dan diterbitkan oleh Badan Pusat Statistik tahun 2015. Selain itu, diperlukan informasi dari perusahaan seperti input antara dan primer, output dan eksternalitas serta kewajiban kepada pemerintah pusat dan daerah.

Data dan informasi yang telah dikumpulkan diolah dengan bantuan komputer, yakni program Microsoft Excel 2010 dan perangkat lunak lainnya. Data dan informasi tersebut sebelumnya dikelompokkan ke dalam biaya dan manfaat, kemudian dilakukan analisis secara kuantitatif.

\section{Model Analisis Input-Output}

Metode kuantitatif digunakan untuk menghitung dan menganalisis model Input-Output
(IO) dengan melihat dampak ekonomi dari kehadiran sektor pertambangan tembaga. Model IO ini digunakan untuk melihat secara nasional kaitan antara sektor pertambangan, khususnya ekstraksi tembaga dengan sektor ekonomi lainnya. Dengan model ini, output, income dan employment multiplier dapat diperoleh dengan membuat analisis tentang dampak dari keberadaan sektor pertambangan tembaga terhadap perekonomian nasional. Model ini dimaksudkan untuk membuat proyeksi produk domestik regional bruto (PDRB), PDRB per-kapita, dan penyerapan lapangan kerja dengan adanya sektor pertambangan tembaga untuk beberapa tahun ke depan. Selain itu, Tabel input-output dapat juga digunakan untuk menganalisis kaitan multisektoral yang dapat menstimulir perekonomian nasional (Nazara, 1997; Tounsi $d k k ., 2013)$. Kerangka penyusunan Tabel IO dapat dilihat dalam Tabel 1.

Tabel IO dapat memberikan beberapa informasi tentang karakteristik sektor tertentu (misalnya, sektor pertambangan), seperti struktur input dari sektor tersebut dan bagaimana output sektor tersebut digunakan sebagai input untuk sektor lain atau untuk memenuhi permintaan akhir. Model IO dapat juga menghasilkan beberapa indikator penting dari suatu sektor. Indikator tersebut adalah pengganda output, pendapatan, dan kesempatan kerja (output, income dan employment multipliers); serta kaitan sektor tersebut ke belakang dan ke depan (backward and forward linkages). Di samping itu, model IO juga dapat digunakan untuk menganalisis dampak perubahan pada permintaan akhir (seperti konsumsi, investasi, pengeluaran pemerintah dan ekspor) terhadap perekonomian nasional (LPEM-FEUI, 2008).

Table 1. Kerangka kerja Input-Output

\begin{tabular}{|c|c|c|c|c|c|c|c|}
\hline & & \multicolumn{4}{|c|}{ Permintaan Antara } & \multirow{3}{*}{$\begin{array}{l}\text { Permintaan } \\
\text { Akhir }\end{array}$} & \multirow{3}{*}{$\begin{array}{l}\text { Output } \\
\text { Total }\end{array}$} \\
\hline & & \multicolumn{4}{|c|}{ Sektor Produksi } & & \\
\hline & & 1 & 2 & $\ldots$ & $\mathrm{N}$ & & \\
\hline \multirow{4}{*}{$\begin{array}{l}\text { Sektor } \\
\text { produksi }\end{array}$} & 1 & $\mathrm{X} 11$ & $\mathrm{X} 12$ & $\ldots$ & $\mathrm{X} 1 \mathrm{n}$ & F1 & $\mathrm{X} 1$ \\
\hline & 2 & $\mathrm{X} 21$ & $\mathrm{X} 22$ & $\ldots$ & $X 2 n$ & $\mathrm{~F} 2$ & $\mathrm{X} 2$ \\
\hline & $\ldots$ & $\ldots$ & $\ldots$ & $\ldots$ & $\ldots$ & $\ldots$ & $\ldots$ \\
\hline & $\mathrm{n}$ & $\mathrm{Xn} 1$ & $\mathrm{Xn} 2$ & $\ldots$ & Xnn & Fn & $\mathrm{Xn}$ \\
\hline \multicolumn{2}{|c|}{ Nilai tambah bruto } & $\mathrm{V} 1$ & V2 & & $\mathrm{Vn}$ & & \\
\hline \multicolumn{2}{|c|}{ Input total } & $\mathrm{X} 1$ & $\mathrm{X} 2$ & $\ldots$ & $\mathrm{Xn}$ & & \\
\hline
\end{tabular}


Model input-output disebut juga dengan model Leontief (Miller dan Blair, 1985) dinotasikan dalam matriks sebagai berikut:

$X=(I-A)^{-1} F$

dalam hal ini,

X adalah vektor kolom output total.

A adalah matriks koefisien input teknik.

$(\mathrm{I}-\mathrm{A})^{-1}$ adalah invers matrik Leontief.

$\mathrm{F} \quad$ Vektor kolom permintaan akhir.

Model tersebut dapat digunakan untuk meramalkan perubahan setiap variabel eksogen, seperti permintaan akhir terhadap sistem perekonomian nasional secara simultan. Kekuatan keterkaitan subsektor pertambangan dengan sektor perekonomian lainnya diukur dengan menggunakan matrik invers Leontief $(\mathrm{I}-\mathrm{A})^{-1}$ sebagai berikut:

1. Indeks daya penyebaran (backward linkage effect), menggambarkan efek relatif dari kenaikan output suatu sektor terhadap peningkatan output sektor lainnya.

2. Indeks derajat kepekaan (forward linkage effect), menggambarkan efek relatif dari peningkatan output suatu sektor terhadap dorongan peningkatan output sektor lainnya (keterkaitan ke belakang)

3. Pengaruh pengganda pendapatan (income multiplier effect)

4. Pengaruh pengganda tenaga kerja (employment multiplier effect)

- Income multiplier (pengganda pendapatan) $\left(=\mathrm{l}_{\mathrm{j}}\right)=\mathrm{b}_{\mathrm{ij}} / \mathrm{l}_{\mathrm{j}}$ dalam hal ini $\mathrm{l}_{\mathrm{j}}=$ koefisien pendapatan sektor-j, $\mathrm{b}_{\mathrm{ij}}=$ matriks kebalikan (Leontief inversed matrix) tiap sektor: Income multiplier adalah perubahan pendapatan yang dihasilkan dari setiap kenaikan satu unit nilai output dari semua industri dalam sektor-sektor pengolah (processing sectors).

- Employment multiplier (pengganda kesempatan kerja) $\left(\mathrm{N}_{\mathrm{j}}\right)=\Sigma \mathrm{l}_{\mathrm{j}} \mathrm{b}_{\mathrm{ij}} / \mathrm{l}_{\mathrm{j}}$; dalam hal ini lj-koefisien employment sektor-j. Employment multiplier adalah perubahan employment yang dihasilkan dari setiap unit nilai final demand (Ruiz-Mercado, 2006).

- Pengganda nilai tambah (Value added multiplier $\left(=\mathrm{v}_{\mathrm{j}}\right)=\Sigma \mathrm{v}_{\mathrm{j}} \mathrm{b}_{\mathrm{ij}} / \mathrm{v}_{\mathrm{j}}$; dalam hal ini $\mathrm{v}_{\mathrm{j}}=$ koefisien nilai tambah).
- Value added meliputi upah/gaji, kapital, surplus usaha, subsidi dan pajak tak langsung.

\section{HASIL DAN PEMBAHASAN}

\section{Kondisi Umum Perekonomian Nasional}

Salah satu indikator perkembangan ekonomi nasional adalah dengan melihat perkembangan PDB. Pada tahun 2000, PDB Indonesia berada pada posisi Rp.1.218 triliun, naik sangat fantastis sebanyak $128,10 \%$ atau menembus angka Rp. 2.779 triliun. Kenaikan ini dipicu oleh tingginya peran industri pengolahan yang memberikan kontribusi sebesar 26,94\% dan sektor perdagangan sebesar $17,05 \%$. Pada tahun 2000, sektor pertambangan memberikan kontribusi sebesar $12,07 \%$, namun pada tahun 2001 kontribusinya turun menjadi 11,68\%. Menurunnya peran sektor pertambangan terus terjadi hingga tahun 2014 dengan penurunan yang cukup signifikan yaitu menjadi sebesar $6,72 \%$ (Gambar 1). Terbitnya UU No. 4 tahun 2009 tentang pertambangan mineral dan batubara, juga turut mempengaruhi turunnya kontribusi sektor pertambangan, karena perusahaan pertambangan sudah tidak diperbolehkan lagi menjual bahan mentah ke luar negeri kecuali diolah atau dimurnikan terlebih dahulu. Namun, menurunnya peran sektor pertambangan ini ternyata tidak mempengaruhi pertumbuhan ekonomi nasional yang naik rata-rata sebesar 5,42\% per tahun. Hal ini karena didukung oleh besarnya kontribusi sektor industri pengolahan, pengangkutan dan komunikasi.

Sektor industri pengolahan memiliki beberapa keunggulan dibandingkan dengan sektor lainnya yaitu nilai kapitalisasi modal yang tertanam sangat besar, kemampuan menyerap tenaga kerja, dan menciptakan nilai tambah dari setiap input atau bahan dasar yang diolah. Sektor industri pengolahan di Indonesia di satu pihak memiliki kontribusi terhadap PDB yang tertinggi dan nilai investasi yang tertanam cukup besar, namun kontribusi tersebut tidak sebanding dengan daya serap tenaga kerja. Sektor industri pengolahan yang merupakan penyumbang PDB terbesar hanya mampu menduduki peringkat ketiga dalam menyerap tenaga kerja setelah sektor pertanian dan perdagangan 
(Kohar, 2008; Putra, 2012). Sektor industri pengolahan yang berkembang sampai saat ini ternyata masih didominasi oleh industri padat tenaga kerja yang memiliki mata rantai relatif pendek, sehingga penciptaan nilai tambah juga relatif kecil. Akan tetapi karena besarnya populasi unit usaha, maka kontribusi terhadap perekonomian tetap besar. Terdapat tiga unsur pelaku ekonomi yang mendukung perkembangan sektor industri, yaitu badan usaha milik swasta (BUMS), badan usaha milik negara (BUMN) dan pengusaha kecil/menengah, serta koperasi/PKMK (Sanwindayani, 2014).

Antara tahun 2000-2014, pertumbuhan terjadi pada seluruh lapangan usaha, kecuali sektor pertambangan yang terkontraksi sebesar 1,12 persen pada 2015. Pertumbuhannya agak melambat bahkan cenderung menurun (Gambar 2).

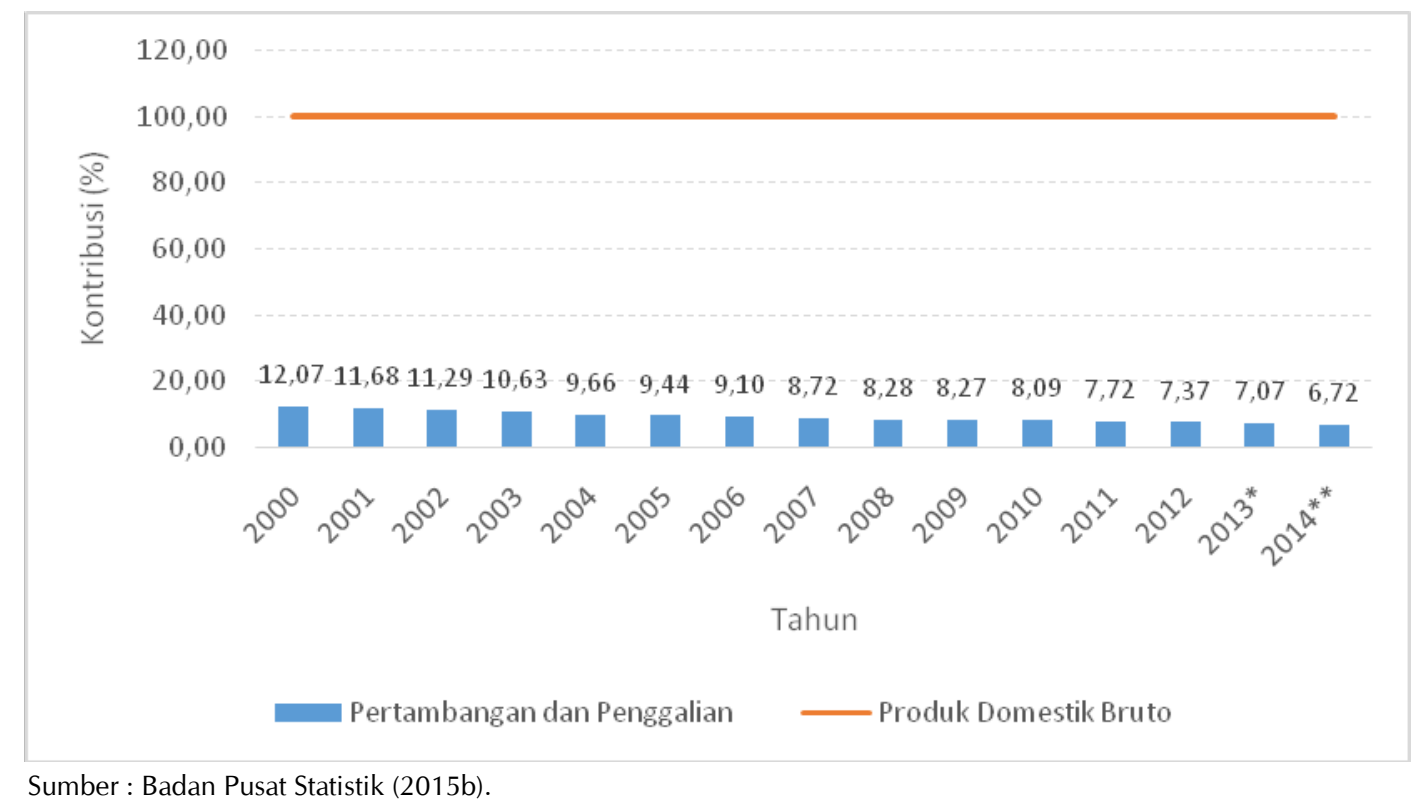

Gambar 1. Kontribusi (\%) sektor pertambangan dan pengalian terhadap PDB, tahun 2000-2014

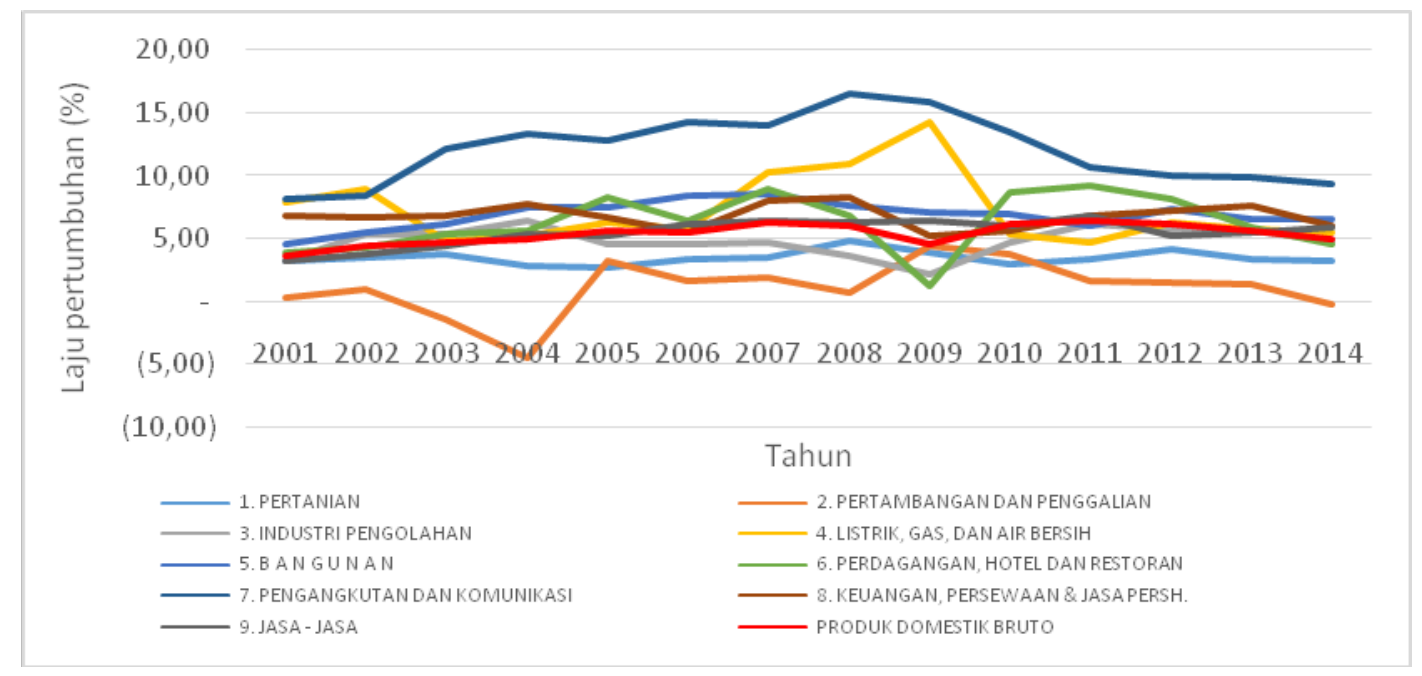

Gambar 2. Laju pertumbuhan setiap sektor perekonomian nasional (\%), tahun 2001-2014 
Diterbitkannya UU No. 4 Tahun 2009, disusul dengan terbitnya Peraturan Menteri No. 8 Tahun 2015 terkait dengan peningkatan nilai tambah mineral dan batubara, ternyata mempengaruhi juga terhadap penerimaan negara di sektor pertambangan tembaga. Indikasi penurunan ini dapat dilihat pada Tabel 2. Dari tahun 2001 sampai dengan 2011, penerimaan dari salah satu perusahaan tembaga terbesar di Indonesia meningkat ratarata $42,8 \%$, namun memasuki tahun 20122014 penerimaan negara dari sektor ini mengalami penurunan hingga $32,71 \%$.

Model input-output ini juga telah digunakan oleh Subanti dan Hakim (2015) dan Hermawan (2014), untuk mengkaji dampak ekonomi terhadap kesempatan kerja, pendapatan dan sektor perekonomian lainnya.

Menurut Subanti dan Hakim (2015), pendapatan masyarakat Indonesia untuk sektor pertambangan dan penggalian sebesar 0,1416 pada tahun 2005 mengalami penurunan dibandingkan dengan tahun 1995 yaitu 0,1675 dan tahun 2000 sebesar 0,1511. Penurunan ini juga berpengaruh terhadap kesempatan kerja. Hal ini terindikasi dari koefisien teknis yang menyatakan bahwa tiap kenaikan output sektor pertambangan tembaga sebesar 1 milyar rupiah berdampak pada penambahan kesempatan kerja bagi perekonomian secara keseluruhan sebesar 27 orang ditahun 1995, 6 orang ditahun 2000 dan 3 orang di tahun 2005.

Soelistijo, Wibowo dan Wibawa (2012) menyatakan bahwa sektor pertambangan memiliki angka pengganda surplus (surplus multiplier) sebesar 8,02 artinya bahwa sektor pertambangan dapat memberikan surplus usaha yang menarik bagi para investor, sedangkan angka pengganda nilai tambah (value added multiplier) sebesar 1,32, menunjukkan bahwa sektor pertambangan dapat memberikan nilai tambah bagi sektor ekonomi lainnya.

\section{Pengganda Output (Output Multiplier)}

Pengganda output yang disajikan dalam kajian ini terdiri dari pengganda, pendapatan dan tenaga kerja. Setelah dilakukan penghitungan dengan bantuan perangkat lunak excel, hasilnya dianalisis dan diuraikan pada pembahasan berikut.

Pengganda output (ke arah belakang) sektor pertambangan bijih logam sebesar 1,524, berarti bahwa setiap satu juta rupiah nilai penjualan sektor pertambangan tembaga berkontribusi menambah output perekonomian nasional menjadi 1,524 juta rupiah (Tabel 3). Komposisinya terdiri dari satu juta rupiah adalah dampak langsung, yaitu nilai penjualan sektor pertambangan tembaga itu sendiri; kemudian 0,263 juta rupiah adalah dampak tidak langsung yaitu peningkatan output di lapangan usaha lainnya akibat adanya mekanisme rantai pasokan (supplychain); dan 0,262 juta rupiah adalah dampak tidak langsung peningkatan ouput di lapangan usaha lainnya akibat adanya belanja rumah tangga yang pendapatannya diterima dari dampak keberadaan usaha sektor pertambangan tembaga. Angka pengganda output sektor pertambangan bijih logam tergolong rendah, karena angka indeks keterkaitannya kurang dari satu, yaitu 0,74. Sebagai informasi, jika angka keterkaitan lebih besar dari satu, sektor dikatakan memiliki keterkaitan tinggi, jika angka keterkaitan sama dengan satu, maka sektor dikatakan memiliki tingkat keterkaitan yang sama dengan rata-rata semua sektor.

Angka pengganda output ke arah depan (hilir) sebesar 1,871 (lihat Tabel 3), artinya dari setiap satu juta rupiah penjualan dari sektor pertambangan tembaga dapat mendorong penciptaan output nasional menjadi 1,871 juta rupiah. Angka ini lebih tinggi daripada pengganda ke arah hulu atau belakang. Komposisinya terdiri dari satu juta rupiah sebagai nilai penjualan dari sektor pertambangan tembaga itu sendiri, 0,762 juta rupiah adalah penambahan output di sektor lapangan usaha lain akibat adanya mekanisme supply-chain, dan 0,109 juta rupiah adalah tambahan output di sektor lainnya akibat peningkatan belanja rumah tangga yang sumber pendapatannya berasal dari sektor pertambangan tembaga.

Pengganda ke arah hilir lebih tinggi jika produk tambang dari sektor pertambangan tembaga diolah lebih lanjut di dalam negeri. Proses pengolahan berpotensi mendorong perkembangan output di sejumlah besar 
industri-industri yang lebih hilir. Hal ini berbeda jika produk tambang dari sektor pertambangan tembaga secara total diekspor. Dampaknya hanya terbatas pada peningkatan output bagi sektor pemasok barang dan jasa, sektor pertambangan tembaga dan sedikit kenaikan output akibat induksi pendapatan. Angka pengganda ouput ini tergolong rendah, karena angka indeks keterkaitannya hanya sebesar 0,71; dari rata-rata angka indeks sebesar 1,00.

Tabel 2. Penerimaan Negara dari perusahaan pertambangan tembaga di Papua

\begin{tabular}{ccccc}
\hline \multirow{2}{*}{ Tahun } & \multicolumn{3}{c}{ Penerimaan Negara (AS\$ Juta) } & \multirow{2}{*}{ Jumlah } \\
\cline { 2 - 4 } & Dividen pemerintah & Royalti & Pajak dan non pajak & \\
\hline 2001 & 4 & 28 & 161 & 193 \\
2002 & 5 & 28 & 161 & 194 \\
2003 & 5 & 36 & 294 & 335 \\
2004 & 9 & 38 & 213 & 260 \\
2005 & 112 & 82 & 686 & 880 \\
2006 & 159 & 146 & 1.294 & 1.599 \\
2007 & 216 & 164 & 1.425 & 1.805 \\
2008 & 49 & 121 & 1.039 & 1.209 \\
2009 & 213 & 128 & 1.013 & 1.354 \\
2010 & 169 & 185 & 1.569 & 1.923 \\
2011 & 202 & 188 & 1.993 & 2.383 \\
2012 & - & 76 & 904 & 980 \\
2013 & - & 101 & 383 & 484 \\
2014 & - & 118 & 421 & 539 \\
\hline Sumber : PT Freeport Indonesinnn
\end{tabular}

Sumber : PT Freeport Indonesia (2016)

Tabel 3. Output Multiplier sektor lapangan usaha pada skala nasional

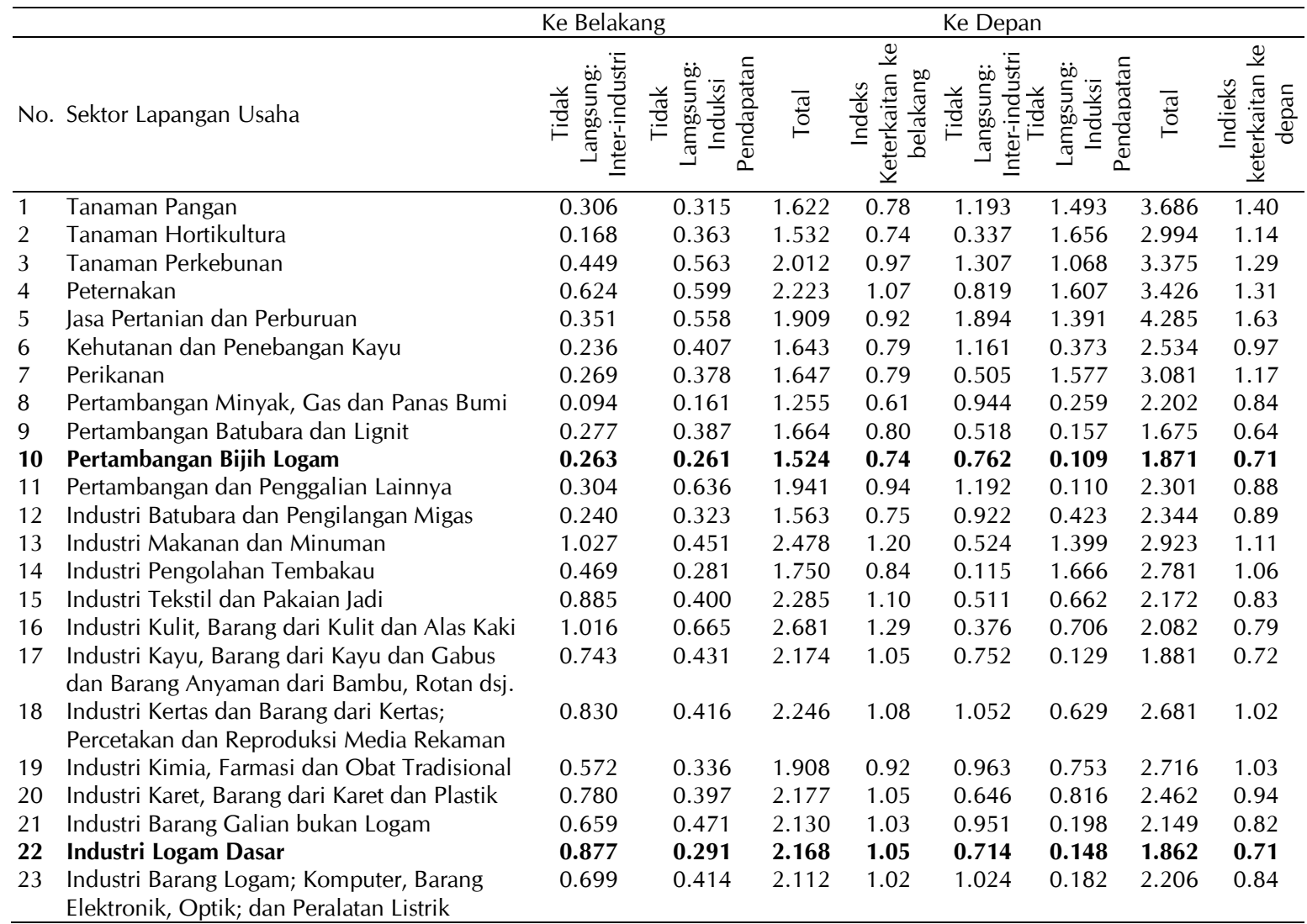




\begin{tabular}{|c|c|c|c|c|c|c|c|c|c|}
\hline & & Ke Belaka & & & & Ke Depan & & & \\
\hline No. & Sektor Lapangan Usaha & 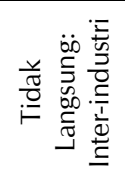 & 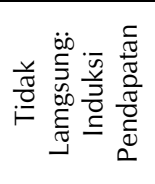 & $\overline{\widetilde{\pi}}$ & 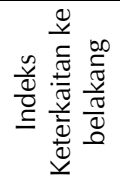 & 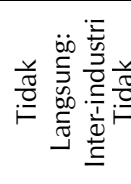 & 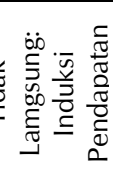 & $\stackrel{\bar{\pi}}{\circ}$ & 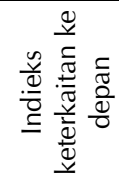 \\
\hline 24 & Industri Mesin dan Perlengkapan & 0.624 & 0.337 & 1.961 & 0.95 & 0.466 & 0.563 & 2.029 & 0.77 \\
\hline 25 & Industri Alat Angk & 0.576 & 0.408 & 1.984 & 0.96 & 0.513 & 1.233 & 2.746 & 1.05 \\
\hline 26 & Industri Furnitur & 0.889 & 0.476 & 2.366 & 1.14 & 0.161 & 0.641 & 1.802 & 0.69 \\
\hline 27 & $\begin{array}{l}\text { Industri Pengolahan Lainnya; Jasa Repa } \\
\text { dan Pemasangan Mesin dan Peralatan }\end{array}$ & 0.779 & 0.439 & 2.219 & 1.07 & 0.314 & 0.693 & 2.007 & 0.76 \\
\hline 28 & Ketenagalistrikan & 0.886 & 0.387 & 2.273 & 1.10 & 1.236 & 1.113 & 3.350 & 1.28 \\
\hline 29 & Pengadaan Gas dan Produksi Es & 0.886 & 0.387 & 2.273 & 1.10 & 1.236 & 1.113 & 3.350 & 1.28 \\
\hline 30 & $\begin{array}{l}\text { Pengadaan Air, Pengelolaan Sampah, Limbah } \\
\text { dan Daur Ulang }\end{array}$ & 0.973 & 0.627 & 2.599 & 1.25 & 1.020 & 1.385 & 3.405 & 1.30 \\
\hline 31 & Konst & 0.818 & 0.493 & 2.311 & 1.12 & 0.140 & 0.070 & 1.209 & 0.46 \\
\hline 32 & $\begin{array}{l}\text { an Mobil, Sepeda Motor dan } \\
\text { y a }\end{array}$ & 0.478 & 0.484 & 1.962 & 0.95 & 0.629 & 1.016 & 2.645 & 1.01 \\
\hline 33 & $\begin{array}{l}\text { Perdagangan Besar dan Eceran, Bukan Mobil } \\
\text { dan Sepeda Motor }\end{array}$ & 0.478 & 0.484 & 1.962 & 0.95 & 0.629 & 1.016 & 2.645 & 1.01 \\
\hline 34 & Angkt & 1.021 & 0.714 & 2.734 & 1.32 & 0.544 & 1.346 & 2.889 & 1.10 \\
\hline 35 & Angk & 0.767 & 560 & 2.327 & 1.12 & 0.719 & 1.137 & 2.856 & 1.09 \\
\hline 36 & Angkt & 0.682 & 0.393 & 2.075 & 1.00 & 0.539 & 0.626 & 2.166 & 0.83 \\
\hline 37 & Ingai Danau dan Penyeberangan & 0.505 & 0.530 & 2.035 & 0.98 & 0.707 & 1.287 & 2.995 & 1.14 \\
\hline 38 & Angkuta & 0.645 & 0.472 & 2.118 & 1.02 & 0.433 & 1.125 & 2.558 & 0.97 \\
\hline 39 & $\begin{array}{l}\text { Pergudangan dan Jasa Penunjang Angkutan; } \\
\text { Pos dan Kurir }\end{array}$ & 0.560 & 0.601 & 2.161 & 1.04 & 0.847 & 0.837 & 2.684 & 1.02 \\
\hline 40 & Penye & & & 2.175 & 1.05 & & 0.538 & 1.848 & 0.70 \\
\hline 41 & Penyec & 0.947 & 0.557 & 2.504 & 1.21 & 0.237 & 1.501 & 2.737 & 1.04 \\
\hline 42 & Informas & 0.272 & 0.383 & 1.655 & 0.80 & 0.706 & 1.215 & 2.921 & 1.11 \\
\hline 43 & Jasa Perantara & & & 985 & 0.96 & & 1.203 & 3.374 & 1.29 \\
\hline 44 & Asur & 380 & 671 & 2.052 & 0.99 & 1.039 & 1.164 & 3.203 & 1.22 \\
\hline 45 & & 375 & 484 & 1.859 & 0.90 & 1.683 & 1.044 & 3.727 & 1.42 \\
\hline 46 & Jasa & 375 & 0.484 & 1.859 & 0.90 & 1.683 & 1.044 & 3.727 & 1.42 \\
\hline 47 & Real Estat & 0.265 & 0.161 & 1.426 & 0.69 & 0.723 & 1.413 & 3.136 & 1.19 \\
\hline 48 & Jasa Perusahaan & 0.530 & 0.555 & 2.085 & 1.01 & 1.116 & 0.678 & 2.794 & 1.06 \\
\hline 49 & $\begin{array}{l}\text { Administrasi Pemerintahan, Pertahanan dan } \\
\text { Jaminan Sosial Wajib }\end{array}$ & 0.610 & 1.151 & 2.761 & 1.33 & 0.036 & 0.043 & 1.079 & 0.41 \\
\hline 50 & & & & & 1.2 & & 0.722 & & 0.68 \\
\hline 51 & Jasa Kesehatan dan Kegiatan Sosial & 0.786 & 0.792 & 2.5 & 1.24 & 0.163 & 0.968 & 2.131 & 0.81 \\
\hline 52 & Jasa lainnya & 0.612 & 0.546 & 2.157 & 1.04 & 0.792 & 1.194 & 2.986 & 1.14 \\
\hline
\end{tabular}

Sumber: Diolah dari Tabel IO Nasional 2010, (Badan Pusat Statistik, 2015a)

\section{Nilai Dampak Ekonomi}

Dampak ekonomi mencakup indikator output perekonomian, nilai tambah bruto dan pendapatan pekerja atau rumah tangga. Dampak ekonomi kemudian dipisahkan ke dalam dampak skala nasional dan skala Provinsi Papua. Setiap indikator dampak dibagi ke dalam 3 komponen, yaitu dampak langsung, antar-industri, dan induksi pendapatan. Dampak langsung adalah peningkatan indikator yang terjadi di sektor pertambangan tembaga, baik dalam bentuk output atau penjualan, nilai tambah bruto maupun pendapatan pekerja di perusahaan. Sebagai catatan, yang tercakup dalam nilai tambah bruto perusahaan adalah komponen upah/gaji, surplus perusahaan, depresiasi, pajak tidak langsung dan subsidi
Pada Tabel 3 disediakan angka penciptaan output sebagai dampak dari operasional sektor pertambangan tembaga dalam periode 2010-2014 pada skala nasional. Angka dampak pada skala nasional selalu lebih besar dari skala kabupaten atau provinsi karena angka dampak nasional menampung dampak lokal dan dampak yang muncul di provinsiprovinsi luar Papua. Kemunculan dampak di luar provinsi Papua sangat dimungkinkan, karena sektor pertambangan tembaga dan sektor lainnya memiliki kaitan dengan usaha lain di Indonesia. Setiap satu juta rupiah nilai penjualan dari usaha sektor pertambangan tembaga akan menciptakan kira-kira 1,75 juta rupiah output nasional (rata-rata periode 2010-2014). Satu juta berasal dari output sektor pertambangan tembaga, dan 0,75 juta 
berasal dari penambahan output di sektor lapangan usaha lain yang terkait langsung dan tidak langsung. Dari tahun ke tahun multiplier output tidak sama, penyebabnya adalah perbedaan proporsi nilai penjulan konsentrat yang diekspor dan diolah di dalam negeri. Jika konsentrat diekspor, maka mutliplier outputnya adalah 1,524, sedangkan jika konsentrat tembaga diolah atau dilebur di dalam negeri maka multiplier output-nya menjadi 1,871. Dalam hal ini pengolahan konsentrat di dalam negeri akan lebih menguntungkan, karena akan memberikan dampak penciptaan output perekonomian yang lebih tinggi dibandingkan diekspor.

Distribusi dampak output secara sektoral dijabarkan oleh angka-angka pada Tabel 4 . Distribusi penciptaan output antar sektor sangat tidak merata, dan memang demikian karakteristik distribusi dampak output antara sektor dari proyek pertambangan. Output terbesar muncul di sektor pertambangan itu sendiri kemudian diikuti oleh sektor industri pengolahan. Sektor-sektor lain yang menerima dampak cukup besar adalah sektor perdagangan dan bengkel kendaraan; sektor transportasi dan pergudangan; sektor jasa keuangan dan asuransi; serta jasa lainnya. Sektor-sektor yang disebutkan di atas adalah sektor-sektor yang dibutuhkan dan didorong oleh pertambangan. Sektor-sektor tersebut terkait kuat dalam sebuah rantai pasokan barang/jasa berbasis industri pertambangan bijih logam tembaga.

Peningkatan nilai output atau penjualan dari sektor pertambangan tembaga secara otomatis melahirkan nilai tambah bruto (NTB) dalam pertambangan bijih logam tembaga dan sektor-sektor lainnya. Nilai tambah bruto yang berasal dari sektor pertambangan tembaga adalah penjumlahan empat komponen yaitu: upah/gaji pekerja produksi dan non produksi dari sektor pertambangan tembaga, surplus usaha sektor pertambangan tembaga, depresiasi barang modal sektor pertambangan tembaga, dan pajak tidak langsung (pajak keluaran yang dibayar pembeli dikurangi pajak masukan yang dibayar perusahaan di sektor pertambangan tembaga). Nilai tambah bruto dari bisnis-bisnis lain di luar sektor pertambangan tembaga adalah penjumlahan empat komponen NTB tersebut, yang terjadi karena bisnis mengalami kenaikan omset atau penjualan sehubungan dengan adanya kegiatan usaha sektor pertambangan tembaga. Angka dampak nilai tambah bruto yang terjadi di sektor pertambangan tembaga dan pihakpihak lain yang terkait pada skala nasional disajikan pada Tabel 5. Perlu dipahami bahwa nilai tambah bruto tidak sama dengan nilai output. Nilai tambah bruto adalah sebuah fraksi atau bagian tertentu dari nilai output, sehingga nilai tambah bruto selalu lebih kecil daripada nilai output. Secara matematis nilai tambah bruto adalah nilai output dikurangi oleh jumlah pengeluaran untuk bahan baku dan penolong (input antara) yang habis sekali proses produksi. Besar-kecilnya nilai tambah bruto bergantung pada intensitas relatif sektor menggunakan input langsung dalam proses produksinya. Nilai output industri yang bersifat ekstraktif (pertanian dan pertambangan) fraksi nilai tambah bruto relatif lebih besar daripada fraksi nilai tambah bruto di sektor manufaktur, bangunan, dan sektorsektor lainnya. Secara umum dapat dikatakan bahwa setiap satu juta rupiah nilai tambah bruto di sektor pertambangan tembaga, akan menciptakan nilai tambah bruto nasional menjadi 1,35 juta rupiah.

Tabel 4. Kontribusi sektor pertambangan tembaga dalam pembentukan output nasional

\begin{tabular}{|c|c|c|c|c|c|}
\hline \multirow[b]{2}{*}{ Tahun } & \multicolumn{4}{|c|}{ (Juta rupiah) } & \multirow[b]{2}{*}{$\begin{array}{c}\text { Output } \\
\text { multiplier } \\
\text { (Rata-rata) }\end{array}$} \\
\hline & $\begin{array}{l}\text { Langsung: } \\
\text { nilai penjualan } \\
\text { industri }\end{array}$ & $\begin{array}{l}\text { Tidak langsung } \\
\text { inter-industrial }\end{array}$ & $\begin{array}{c}\text { Tidak langsung: } \\
\text { induksi } \\
\text { pendapatan }\end{array}$ & Total dampak & \\
\hline 2010 & 67.610 .375 & 15.706 .572 & 29.740 .376 & 113.057 .323 & 1,67 \\
\hline 2011 & 50.438 .516 & 11.335 .808 & 24.438 .332 & 86.212 .656 & 1,71 \\
\hline 2012 & 39.256 .038 & 8.568 .212 & 20.521 .286 & 68.345 .536 & 1,74 \\
\hline 2013 & 46.479 .932 & 10.619 .334 & 21.498 .348 & 78.597 .615 & 1,69 \\
\hline 2014 & 41.367 .243 & 8.874 .117 & 22.538 .922 & 72.780 .282 & 1,76 \\
\hline
\end{tabular}

Sumber: Hasil simulasi model, 2015 
Tabel 5. Kontribusi sektor pertambangan tembaga dalam pembentukan output nasional

\begin{tabular}{|c|c|c|c|c|c|c|c|}
\hline No. & Sektor Lapangan Usaha & 2010 & 2011 & 2012 & 2013 & 2014 & $\%$ \\
\hline 1 & $\begin{array}{l}\text { Pertanian, Kehutanan, } \\
\text { Perikanan }\end{array}$ & 2.426 .873 & 1.737 .935 & 1.304 .254 & 1.634 .469 & 1.344 .944 & 1,85 \\
\hline 2 & $\begin{array}{l}\text { Pertambangan dan } \\
\text { Penggalian }\end{array}$ & 68.639 .707 & 51.168 .320 & 39.798 .642 & 47.169 .750 & 41.923 .564 & 57,60 \\
\hline 3 & Industri Pengolahan & 25.061.199 & 20.653 .384 & 17.379 .339 & 18.143.997 & 19.108 .569 & 26,26 \\
\hline 4 & $\begin{array}{l}\text { Pengadaan Listrik dan } \\
\text { Gas }\end{array}$ & 475.634 & 323.543 & 230.953 & 312.352 & 230.673 & 0,32 \\
\hline 5 & $\begin{array}{l}\text { Pengadaan Air, } \\
\text { pengelolaan sampah, } \\
\text { limbah }\end{array}$ & 66.257 & 50.843 & 40.514 & 46.211 & 43.267 & 0,06 \\
\hline 6 & Konstruksi & 4.324 .307 & 3.735 .255 & 3.246 .641 & $3,210.946$ & 3.627 .976 & 4,98 \\
\hline 7 & $\begin{array}{l}\text { Perdagangan, Reparasi } \\
\text { Mobil dan Speda Motor }\end{array}$ & 2.899 .872 & 2.014.216 & 1.468 .224 & $1,923.830$ & 1.486 .642 & 2,04 \\
\hline 8 & $\begin{array}{l}\text { Transportasi dan } \\
\text { Pergudangan }\end{array}$ & 1.774 .334 & 1.244 .866 & 916.325 & $1,182.941$ & 933.609 & 1,28 \\
\hline 9 & $\begin{array}{l}\text { Akomodasi dan Makan- } \\
\text { minum }\end{array}$ & 1.070 .693 & 760.876 & 566.931 & 718.354 & 582.043 & 0,80 \\
\hline 10 & $\begin{array}{l}\text { Informasi dan } \\
\text { Komunikasi }\end{array}$ & 559.951 & 380.993 & 272.030 & 367.768 & 271.745 & 0,37 \\
\hline 11 & $\begin{array}{l}\text { Jasa Keuangan dan } \\
\text { Asuransi }\end{array}$ & 1.319 .545 & 900.020 & 644.223 & 867.686 & 644.614 & 0,89 \\
\hline 12 & Real estate & 610.227 & 412.546 & 292.619 & 399.548 & 291.024 & 0,40 \\
\hline 13 & Jasa Per & 464.715 & 327.890 & 242.664 & 310.687 & 248.085 & 0,34 \\
\hline 14 & $\begin{array}{l}\text { Administrasi } \\
\text { Pemerintahan, } \\
\text { Pertahanan dan Jaminan } \\
\text { Sosial Wajib }\end{array}$ & 374.048 & 342.221 & 308.467 & 286.686 & 350.702 & 0,48 \\
\hline 15 & Jasa Pendidikan & 517.319 & 418.187 & 346.979 & 370.724 & 378.735 & 0,52 \\
\hline 16 & $\begin{array}{l}\text { Jasa Kesehatan dan } \\
\text { Kegiatan social }\end{array}$ & 383.928 & 298.656 & 240.603 & 269.661 & 258.511 & 0,36 \\
\hline \multirow[t]{2}{*}{17} & Jasa Lainnya & 2.088 .715 & 1.442 .906 & 1.046 .129 & 1.382 .003 & 1.055 .580 & 1,45 \\
\hline & TOTAL & 113.057 .323 & 86.212 .656 & 68.345 .536 & 78.597 .615 & 72.780 .282 & 100,00 \\
\hline
\end{tabular}

Sumber: Hasil Simulasi Model, 2015

Jika dikaitkan dengan angka PDB nasional, maka nilai PDB yang disumbang secara langsung dan tidak langsung oleh kehadiran sektor pertambangan tembaga adalah sekitar $1,14 \%$ dari total PDB nasional pada tahun 2010 (Tabel 6). Kontribusi sektor pertambangan tembaga berkurang menjadi $0,45 \%$ pada tahun 2014. Angka-angka kontribusi sektor pertambangan tembaga tersebut tergolong besar, jika mengingat terdapat ratusan perusahaan pertambangan yang beroperasi di Indonesia.

Sektor pertambangan serta sektor eksploitatif lainnya adalah sektor-sektor yang secara alami memberikan fraksi nilai tambah bruto yang lebih besar dibandingkan sektor lainnya. Lebih besar di sini maksudnya bila dilihat dari fraksi nilai tambah relatif terhadap nilai output. Fraksi output yang menjadi nilai tambah bruto seklitar $80 \%$, artinya dari satu juta rupiah nilai produksi pertambangan akan menghasilkan nilai tambah bruto sebesar 0,80 juta rupiah. Sebagai pembanding, angka fraksi nilai tambah bruto dari sektor industri manufaktur sebesar 0,38 . Dengan penjelasan tersebut, maka sangat wajar jika distribusi sektoral dari nilai tambah bruto yang ada pada Tabel 7 sangat timpang. Dari Tabel 7, diketahui bahwa sektor pertambangan dan penggalian menghasilkan angka terbesar, lalu diikuti oleh sektor industri pengolahan, perdagangan, dan pertanian, kehutanan dan perikanan; serta jasa keuangan dan asuransi. Angka nilai tambah bruto dalam bahasa sehari-hari disebut produk domestik bruto atau PDB. 
Tabel 6. Kontribusi sektor pertambangan tembaga dalam pembentukan Nilai Tambah Bruto Nasional

\begin{tabular}{cccccc}
\hline \multirow{2}{*}{ Tahun } & $\begin{array}{c}\text { Langsung: } \\
\text { Nilai Tambah } \\
\text { Bruto di } \\
\text { Perusahaan }\end{array}$ & $\begin{array}{c}\text { Tidak langsung: } \\
\text { Efek antar- } \\
\text { industrial }\end{array}$ & $\begin{array}{c}\text { Tidak langsung: } \\
\text { Efek induksi } \\
\text { pendapatan }\end{array}$ & Dampak Total & $\begin{array}{c}\text { Nilai Tambah } \\
\text { Multiplier Rata- } \\
\text { rata }\end{array}$ \\
\cline { 2 - 4 } & \multicolumn{2}{c}{ (Juta rupiah) } & \\
\hline 2010 & 54.742 .325 & 7.509 .084 & 11.493 .884 & 73.745 .293 & 1,35 \\
2011 & 40.838 .727 & 5.448 .693 & 9.001 .308 & 55.288 .727 & 1,35 \\
2012 & 31.784 .571 & 4.138 .542 & 7.290 .130 & 43.213 .244 & 1,36 \\
2013 & 37.633 .566 & 5.090 .607 & 8.101 .184 & 50.825 .358 & 1,35 \\
2014 & 33.493 .958 & 4.298 .917 & 7.855 .403 & 45.648 .278 & 1,36 \\
\hline
\end{tabular}

Sumber: Hasil Simulasi Model, 2015

Tabel 7. Kontribusi sektor pertambangan tembaga dalam pembentukan PDB nasional

\begin{tabular}{cccc}
\hline Tahun & $\begin{array}{c}\text { PDB Kontribusi sektor pertambangan } \\
\text { tembaga } \\
\text { (Miliar Rupiah) }\end{array}$ & $\begin{array}{c}\text { PDB-Nasional } \\
\text { (Miliar Rupiah) }\end{array}$ & $\begin{array}{c}\% \text { terhadap PDB } \\
\text { Nasional }\end{array}$ \\
\hline 2010 & 73.745 & 6.446 .852 & $1,14 \%$ \\
2011 & 55.289 & 7.419 .187 & $0,75 \%$ \\
2012 & 43.213 & 8.230 .926 & $0,53 \%$ \\
2013 & 50.825 & 9.087 .277 & $0,56 \%$ \\
2014 & 45.648 & 10.094 .929 & $0,45 \%$ \\
\hline
\end{tabular}

Sumber: Hasil Simulasi Model, 2015

Indikator dampak ekonomi penting lainnya adalah pendapatan pekerja yang diterima rumah tangga, sebagaimana angka-angkanya dicantumkan pada Tabel 8. Pendapatan pekerja adalah indikator yang lebih baik dibandingkan NTB dalam menggambarkan manfaat kehadiran entitas bisnis di suatu wilayah. Manfaat ekonomi NTB belum tentu dirasakan oleh masyarakat domestik atau masyarakat setempat, karena bagian keuntungan perusahaan (komponen kedua dari NTB) umumnya dirasakan oleh pemilik usaha yang domisilinya di luar lokasi perusahaan. Apalagi perusahaan PMA, maka sebagian dividen keuntungan akan dikirim keluar negeri. Komponen depresiasi (komponen ketiga dari NTB) juga tidak dirasakan oleh masyarakat setempat, karena komponen ini akan dinikmati oleh pemodal besar yang berasal dari luar wilayah. Komponen pajak tidak langsung (komponen keempat NTB) juga tidak seutuhnya dinikmati oleh masyarakat setempat, karena dipungut oleh pemerintah pusat.

Jika dibandingkan antara angka dampak pendapatan total pada skala nasional dan pendapatan pekerja di sektor pertambangan tembaga maka diperoleh angka pengganda pendapatan (income multiplier) nasional pada sektor pertambangan tembaga. Dari Tabel 8 diperolah rata-rata income multiplier sebesar 1,89 . Artinya untuk setiap satu juta rupiah pendapatan upah/gaji pekerja di sektor pertambangan tembaga akan meningkatkan pendapatan pekerja skala nasional menjadi 1,89 juta rupiah. Satu juta adalah angka pendapatan yang diterima bekerja di sektor pertambangan tembaga dan 0,89 juta rupiah adalah pendapatan yang diterima oleh seluruh pekerja di sektor lain yang terkait langsung dan tidak langsung dengan aktifitas usaha sektor pertambangan tembaga. Sumber pendapatan masyarakat terbesar adalah dari efek langsung, yaitu bersumber dari pendapatan para pekerja langsung baik berstatus pekerja produksi maupun pekerja non produksi. Urutan kedua terbesar berasal dari efek induksi pendapatan, mencapai $29,63 \%$ dari total dampak pendapatan. Artinya efek penambahan output pada sektor-sektor ekonomi lainnya lebih banyak berasal dari efek tidak langsung belanja barang rumah tangga, dibandingkan efek dari belanja perusahaan. Efek kenaikan output secara otomatis berimplikasi pada kenaikan pendapatan rumah tangga. 
Tabel 8. Kontribusi sektor pertambangan tembaga dalam pembentukan nilai tambah bruto nasional

\begin{tabular}{|c|c|c|c|c|c|c|c|}
\hline No. & Sektor Lapangan Usaha & 2010 & 2011 & 2012 & 2013 & 2014 & $\%$ \\
\hline 1 & $\begin{array}{l}\text { Pertanian, Kehutanan, } \\
\text { Perikanan }\end{array}$ & 1.847 .590 & 1.320 .996 & 989.897 & 1.243 .346 & 1.019 .858 & 2,23 \\
\hline 2 & $\begin{array}{l}\text { Pertambangan dan } \\
\text { Penggalian }\end{array}$ & 55.604 .889 & 41.448 .859 & 32.237 .197 & 38.210 .954 & 33.957 .386 & 74,39 \\
\hline 3 & Industri Pengolahan & 7.689.282 & 6.196 .430 & 5.129 .391 & 5.501 .272 & 5.592 .026 & 12,25 \\
\hline 4 & Pengadaan Listrik dan Gas & 136.800 & 93.056 & 66.426 & 89.837 & 66.345 & 0,15 \\
\hline 5 & $\begin{array}{l}\text { Pengadaan Air, } \\
\text { pengelolaan sampah, } \\
\text { limbah }\end{array}$ & 29.403 & 22.562 & 17.979 & 20.507 & 19.200 & 0,04 \\
\hline 6 & Konstruksi & 1.546 .457 & 1.335 .801 & 1.161 .063 & 1.148 .298 & 1.297 .436 & 2,84 \\
\hline 7 & $\begin{array}{l}\text { Perdagangan, Reparasi } \\
\text { Mobil dan Speda Motor }\end{array}$ & 1.895 .664 & 1.316 .705 & 959.787 & $1,257.619$ & 971.827 & 2,13 \\
\hline 8 & $\begin{array}{l}\text { Transportasi dan } \\
\text { Pergudangan }\end{array}$ & 707.006 & 497.022 & 366.550 & 471.820 & 373.916 & 0,82 \\
\hline 9 & $\begin{array}{l}\text { Akomodasi dan Makan- } \\
\text { minum }\end{array}$ & 477.306 & 339.607 & 253.332 & 320.430 & 260.270 & 0,57 \\
\hline 10 & Informasi dan Komunikasi & 437.174 & 297.454 & 212.383 & 287.129 & 212.161 & 0,46 \\
\hline 11 & $\begin{array}{l}\text { Jasa Keuangan dan } \\
\text { Asuransi }\end{array}$ & 866.526 & 590.917 & 422.889 & 569.744 & 423.091 & 0,93 \\
\hline 12 & Real estate & 507.053 & 342.795 & 243.144 & 331.994 & 241.819 & 0,53 \\
\hline 13 & Jasa Perusahaan & 255.753 & 180.452 & 133.549 & 170.985 & 136.532 & 0,30 \\
\hline 14 & $\begin{array}{l}\text { Administrasi Pemerintahan, } \\
\text { Pertahanan dan Jaminan } \\
\text { Sosial Wajib }\end{array}$ & 216.425 & 198.010 & 178.480 & 165.878 & 202.918 & 0,44 \\
\hline 15 & Jasa Pendidikan & 311.481 & 251.793 & 208.918 & 223.215 & 228.038 & 0,50 \\
\hline 16 & $\begin{array}{l}\text { Jasa Kesehatan dan } \\
\text { Kegiatan sosial }\end{array}$ & 182.648 & 142.081 & 114.463 & 128.287 & 122.982 & 0,27 \\
\hline 17 & Jasa Lainnya & 1.033 .837 & 714.186 & 517.796 & 684.041 & 522.474 & 1.14 \\
\hline & TOTAL & 73.745 .293 & 55.288 .727 & 43.213 .244 & 50.825 .358 & 5.648 .278 & 00,00 \\
\hline
\end{tabular}

Sumber: Hasil Simulasi Model, 2015

Pola distribusi dampak pendapatan disajikan pada Tabel 9, terlihat bahwa pendapatan lebih tersebar ke lebih banyak sektor dibanding distribusi dampak output. Walaupun dampak output dan NTB masih terpusat dari sektor pertambangan dan penggalian, namun dampak pendapatan lebih tersebar ke sektor lainnya. Penjelasannya adalah karena fraksi pendapatan-output di sektor lain lebih besar dari fraksi pendapatan-output di sektor pertambangan dan penggalian. Oleh karena itu, walaupun nilai tambah brutonya kecil, namun penciptaan pendapatan rumah tangganya relatif lebih besar. Inilah suatu fenomena eksternalitas positif dari pertambangan dalam rantai penciptaan pendapatan rumah tangga. Rantai penciptaan pendapatan rumah tangga akan semakin besar lagi jika produk-produk pertambangan diolah lebih lanjut menjadi produk-produk setengah jadi atau produk akhir. Selain itu kontribusi pendapatan akan dapat ditingkatkan sejalan dengan peningkatan input domestik.

\section{Manfaat Makroekonomi Tingkat Nasional}

Pada tahun 2010, keberadaan sektor pertambangan tembaga memberikan kontribusi langsung dan tidak langsung dalam pembentukan PDB nasional sebesar Rp 73,74 triliun atau $1,14 \%$ dari total PDB nasional; kontribusinya berkurang menjadi Rp 45,65 triliun atau 0,45\% dari total PDB pada tahun 2014. Penurunan kontribusi secara makro tersebut, di satu pihak berasal dari berkurangnya produksi dan penjualan di sektor pertambangan tembaga dalam beberapa tahun terakhir, dan di lain pihak akibat penambahan kapasitas perekonomian nasional melampaui penambahan kapasitas produksi sektor pertambangan tembaga. Secara singkat periode 2010-2014, kontribusi sektor pertambangan tembaga rata-rata $0,65 \%$ dari total PDB Nasional. Kenaikan kontribusi terhadap PDB juga diikuti oleh penciptaan pendapatan rumah tangga. Pada periode 20102014 ini, sektor pertambangan tembaga berkontribusi menambah pendapatan rumah tangga nasional sebesar Rp 9,25 trilliun per tahun. 
Tabel 9. Kontribusi sektor pertambangan tembaga dalam pembentukan pendapatan pekerja atau rumah tangga nasional (juta rupiah)

\begin{tabular}{cccccc}
\hline Tahun & $\begin{array}{c}\text { Langsung: } \\
\text { Perkiraan } \\
\text { Pendapatan } \\
\begin{array}{c}\text { Pekerja di sektor } \\
\text { pertambangan } \\
\text { tembaga }\end{array}\end{array}$ & $\begin{array}{c}\text { Tidak Langsung: } \\
\text { Efek intar- } \\
\text { industrial }\end{array}$ & $\begin{array}{c}\text { Tidak Langsung: } \\
\text { Efek induksi } \\
\text { Pendapatan }\end{array}$ & $\begin{array}{c}\text { Pengganta } \\
\text { Anga Dampak } \\
\text { Total }\end{array}$ & $\begin{array}{c}\text { Pendapatan } \\
\text { (income } \\
\text { multiplier) }\end{array}$ \\
\hline 2010 & 6.768 .112 & 2.259 .177 & 3.551 .451 & 12.578 .740 & 1,86 \\
2011 & 5.049 .129 & 1.647 .409 & 2.820 .051 & 9.516 .589 & 1,88 \\
2012 & 3.929 .711 & 1.256 .851 & 2.308 .573 & 7.495 .136 & 1,91 \\
2013 & 4.652 .857 & 1.535 .353 & 2.521 .283 & 8.709 .493 & 1,87 \\
2014 & 4.141 .053 & 1.309 .028 & 2.501 .987 & 7.952 .068 & 1,92 \\
\hline
\end{tabular}

Sumber: Hasil Simulasi Model, 2015

Efek pengganda tenaga kerja (employment multiplier) adalah hasil perkalian matrik rasio tenaga kerja dengan matrik invers Leontief. Hasilnya adalah multiplier tenaga kerja (Mahmoud Al Zoubi, 2013). Rumusnya adalah:

$M E=L^{\wedge}(I-A)^{-1}$

$L^{\wedge}$ adalah matriks koefisien tenaga kerja yang berisi rasio tenaga kerja terhadap total input tiap sektor.

Matriks ini adalah matriks diagonal dengan komponennya diperoleh dari

$\mathrm{l}_{\mathrm{j}}=\mathrm{TK}_{j} / \mathrm{X}_{j}$

dalam hal ini, $\mathrm{TK}_{\mathrm{j}}$ adalah jumlah tenaga kerja sektor j, $\mathrm{Xj}$ adalah total input sektor j Perubahan jumlah tenaga kerja yang dibutuhkan karena perubahan permintaan akhir domestik tiap sektor (Subanti dan Hakim, 2009; Bess dan Ambargis, 2011) dirumuskan dengan:

$T K=L^{\wedge}(I-A)^{-1} F$

Dari sini dapat dilihat bahwa dampak pengganda tenaga kerja dipengaruhi oleh adanya perubahan permintaan akhir dari sektor pertambangan tembaga di Papua. Dengan kata lain bahwa setiap kenaikkan permintaan akhir sektor pertambangan tembaga di Papua sebesar satu unit (dalam miliar rupiah) akan menciptakan kesempatan kerja sebanyak 9,97 orang. Komposisinya terdiri dari satu orang sebagai pekerja di sektor pertambangan tembaga itu sendiri, 2,83 orang yang bekerja di sektor lainnya akibat mekanisme keterkaitan intra-industri, dan 6,15 orang yang bekerja di sektor lainnya.

Kesempatan kerja secara nasional yang muncul sebagai dampak langsung dan tidak langsung dari kehadiran perusahaan tembaga di Papua adalah sebanyak 222 ribu orang pada tahun 2010, kemudian menjadi 275 ribu orang pada tahun 2014. Sekalipun penjualan menurun, perusahaan ini tetap mempertahankan jumlah tenaga kerja yang sudah direkrutnya, yaitu sekitar 32 ribu orang pada 2014. Pengganda tenaga kerja kegiatan pertambangan yang menghasilkan konsentrat yang mengandung logam tembaga adalah 8,61. Angka ini mengandung arti bahwa setiap pekerja sektor pertambangan tembaga di Papua mampu membangkitkan (generate) tenaga kerja sebanyak 8,61 orang, yang terdiri dari satu orang bekerja di perusahaan tembaga itu sendiri dan 7,61 orang bekerja di sektor luar pertambangan bijih logam. Dengan kata lain bahwa, setiap kenaikan permintaan akhir sektor pertambangan tembaga di Papua sebesar satu miliar rupiah akan menciptakan kesempatan kerja sebanyak 8,61 orang. Komposisinya terdiri dari satu orang sebagai pekerja di sektor pertambangan, 7,61 orang yang bekerja di sektor lainnya akibat mekanisme keterkaitan antar-industri. 
Tabel 10. Kontribusi sektor pertambangan tembaga dalam pembentukan pendapatan rumah pekerja nasional (juta rupiah)

\begin{tabular}{llcccccc}
\hline No. & \multicolumn{1}{c}{ Sektor Lapangan Usaha } & 2010 & 2011 & 2012 & 2013 & 2014 & $\%$ \\
\hline 1 & Pertanian, Kehutanan, Perikanan & 422.813 & 303.914 & 228.859 & 285.287 & 236.494 & 2,97 \\
2 & Pertambangan dan Penggalian & 6.890 .848 & 5.138 .299 & 3.997 .516 & 4.736 .115 & 4.211 .533 & 52,96 \\
3 & Industri Pengolahan & 2.190 .113 & 1.761 .850 & 1.456 .567 & 1.565 .479 & 1.586 .858 & 19,96 \\
4 & Pengadaan Listrik dan Gas & 42.007 & 28.575 & 20.397 & 27.586 & 20.372 & 0,26 \\
& Pengadaan Air, pengelolaan & 12.303 & 9.441 & 7.523 & 8.580 & 8.034 & 0,10 \\
5 & sampah, limbah & 574.752 & 496.460 & 431.517 & 426.773 & 482.201 & 6,06 \\
6 & Konstruksi & 537.699 & 373.479 & 272.240 & 356.720 & 275.656 & 3,47 \\
7 & Perdagangan, Reparasi Mobil & & & & & \\
& dan Speda Motor & & & & & \\
8 & Transportasi dan Pergudangan & 292.385 & 205.573 & 151.629 & 195.136 & 154.689 & 1,95 \\
9 & Akomodasi dan Makan-minum & 170.784 & 121.392 & 90.468 & 114.595 & 92.891 & 1,17 \\
10 & Informasi dan Komunikasi & 87.977 & 59.860 & 42.740 & 57.782 & 42.695 & 0,54 \\
11 & Jasa Keuangan dan Asuransi & 259.522 & 176.783 & 126.373 & 170.546 & 126.339 & 1,59 \\
12 & Real estate & 25.602 & 17.309 & 12.277 & 16.763 & $12, .210$ & 0,15 \\
13 & Jasa Perusahaan & 94.469 & 66.655 & 49.330 & 63.158 & 50.432 & 0,63 \\
& Administrasi Pemerintahan, & & & & & & \\
& Pertahanan dan Jaminan Sosial & 190.705 & 174.478 & 157.269 & 146.165 & 178.802 & 2,25 \\
14 & Wajib & & & & & & \\
15 & Jasa Pendidikan & 246.055 & 198.904 & 165.035 & 176.329 & 180.140 & 2,27 \\
& Jasa Kesehatan dan Kegiatan & 115.886 & 90.147 & 72.624 & 81.395 & 78.030 & 0,98 \\
16 & Sosial & 424.820 & 293.470 & 212.771 & 281.084 & 214.693 & 2,70 \\
\hline & Jasa Lainnya & 12.578 .740 & 9.516 .589 & 7.495 .136 & 8.709 .493 & 7.952 .068 & 100,00 \\
\hline
\end{tabular}

Sumber: Hasil Simulasi Model, 2015

Tabel 11. Multiplier kesempatan kerja berdasarkan sektor lapangan usaha pada skala nasional

\begin{tabular}{|c|c|c|c|c|}
\hline No. & Sektor Lapangan Usaha & $\begin{array}{c}\text { Dampak } \\
\text { Langsung }\end{array}$ & Tidak Langsung & Total \\
\hline 1 & \multirow[t]{2}{*}{ Tanaman Pangan } & \multirow[t]{2}{*}{1} & \multirow[t]{2}{*}{0.06} & \multirow[t]{2}{*}{1.15} \\
\hline . & & & & \\
\hline 9 & Pertambangan Batubara dan Lignit & 1 & 2.86 & 4.74 \\
\hline 10 & Pertambangan Bijih Tembaga & 1 & 6.15 & 9.97 \\
\hline 11 & Pertambangan dan Penggalian Lainnya & 1 & 0.76 & 1.95 \\
\hline$\cdot$ & & & & \\
\hline 22 & \multirow{3}{*}{$\begin{array}{l}\text { Industri Pengolahan Tembaga } \\
\text { Industri Barang Logam; Komputer, Barang Elektronik, } \\
\text { Optik; dan Peralatan Listrik }\end{array}$} & 1 & 7,61 & 8,61 \\
\hline 23 & & 1 & 2.60 & 5.21 \\
\hline$\cdot$ & & & & \\
\hline 52 & Jasa lainnya & 1 & 0.50 & 1.81 \\
\hline
\end{tabular}

Sumber: Diolah dari Tabel IO Nasional 2005, BPS.

Berdasarkan perhitungan dengan menggunakan rumus $M E=L^{\wedge}(I-A)^{-1}$ 


\section{KESIMPULAN DAN SARAN}

\section{Kesimpulan}

Peran sektor pertambangan tembaga di Papua melalui kontribusi langsung maupun tidak langsung terhadap perekonomian nasional sangat besar, kontribusi dalam pembentukan PDB nasional sebesar Rp 73,74 triliun atau $1,14 \%$ dari total PDB nasional tahun 2010. Namun kontribusi tersebut berkurang menjadi Rp 45,65 triliun atau $0,45 \%$ dari total PDB pada tahun 2014. Periode 2010-2014 kontribusi sektor pertambangan tembaga secara rata-rata adalah $0,65 \%$ dari total PDB Nasional.

Penurunan kontribusi secara makro tersebut, di satu pihak disebabkan oleh berkurangnya produksi dan penjualan di sektor pertambangan tembaga dalam beberapa tahun terakhir, di lain pihak akibat penambahan kapasitas perekonomian nasional melampaui penambahan kapasitas produksi sektor pertambangan tembaga.

Salah satu penyebab turunnya produksi dan penjualan tersebut disebabkan oleh adanya pemberlakuan UU No. 4 tahun 2009 tentang Pertambangan Mineral dan Batubara dan Permen ESDM No. 8 Tahun 2015 tentang Peningkatan Nilai Tambah Mineral dan Batubara.

\section{Saran}

Walaupun adanya pemberlakuan UU No. 4 tahun 2009 dan ESDM No. 8 Tahun 2015 tersebut memperlambat pertumbuhan sektor pertambangan untuk beberapa tahun terakhir ini, namun diharapkan pemerintah maupun perusahaan tetap konsisten melaksanakan UU No. 4/2009 serta Permen ESDM No.8/2015, karena komitmen perusahaan untuk membangun pabrik pengolahan dan pemurnian mineral tembaga beberapa tahun ke depan diperkirakan akan mampu menumbuhkan kembali sektor pertambangan dan perekonomian nasional secara signifikan.

\section{UCAPAN TERIMA KASIH}

Pada kesempatan ini, ucapan terima kasih disampaikan kepada semua pihak lembaga/ instansi maupun pribadi yang telah memberikan saran dan masukan, baik langsung maupun tidak langsung sehingga terwujudnya hasil kajian ini dan semoga pula kajian ini bermanfaat bagi bagi para pelaku usaha mineral logam tembaga, pemerintah, peneliti dan pemerhati mineral logam tembaga.

\section{DAFTAR PUSTAKA}

Badan Pusat Statistik (2015a) Laporan perekonomian Papua tahun 2015. Jayapura.

Badan Pusat Statistik (2015b) Penyusunan tabel input-output tahun 2010. Jakarta.

Bess, R. and Ambargis, Z. O. (2011) Input-Output Models for Impact Analysis:Suggestions for Practitioners Using RIMS II Multipliers, The 50th Southern Regional Science Association Conference. U.S. Department of Commerce: Bureau of Economic Analysis. Available at: https://www.researchgate.net/publication/241 752426 Input-

Output_Models_for_Impact_AnalysisSuggesti ons_for_Practitioners_Using_RIMS_II_Multipli ers.

Hermawan, H. R. (2014) Pengaruh sektor pertambangan terhadap pertumbuhan ekonomi dan pembangunan manusia. Institut Pertanian Bogor. Available at: http://repository.ipb.ac.id/handle/123456789/ 71322.

Kohar, A. (2008) "Peranan sektor perikanan pada perekonomian Jawa Tengah: Pendekatan model," Jurnal Saintek Perikanan, 4(1), pp. 28-34. doi: 10.14710/ijfst.4.1.p.

LPEM-FEUI (2008) Dampak ekonomi dan fiskal PTFI terhadap perekonomian Papua. Jakarta.

Mahmoud Al Zoubi, O. (2013) "Economic multipliers for Jordanian economy:(Inputoutput analysis)," Global Journal of Management And Business Research, 13(7B), pp. 15-24. Available at: https://journalofbusiness.org/index.php/GJMB R/article/view/1141.

Miller, R. E. and Blair, P. D. (1985) Input-output analysis: foundations and extensions. New Jersey: Englewood Cliffs.

Nazara, S. (1997) Analisis Input-Output. Jakarta: Fakultas Ekonomi Universitas Indonesia. 
PT Freeport Indonesia (2016) Fakta Freeport Indonesia, PT Freeport Indonesia. Available at: http://ptfi.co.id/id/media/facts-aboutfeeport-indonesia (Accessed: March 1, 2016).

Putra, G. S. A. (2012) Analisis peranan dan dampak investasi sektor industri pengolahan terhadap perekonomian Indonesia. Institut Pertanian Bogor. Available at: http://repository.ipb.ac.id/bitstream/handle/12 $3456789 / 55806 / \mathrm{H} 12$ gsa.pdf? sequence $=9$ \& is Allowed $=y$.

Ruiz-Mercado, A. L. (2006) "Estimate of multipliers for The Puerto Rican economy," Revista Empresarial Inter Metro / Inter Metro Business Journal, 2(2), pp. 59-68. Available at: http://ceajournal.metro.inter.edu/fall06/ruizm ercado0202.pdf.

Sanwindayani (2014) Sektor-sektor perekonomian Indonesia,

https://sanwindayani.wordpress.com.

Available https://sanwindayani.wordpress.com/2014/04/ 04/sektor-sektor-perekonomian-indonesia/ (Accessed: March 1, 2016).

Soelistijo, U. W., Wibowo, A. P. and Wibawa, H. (2012) "Peranan subsektor pertambangan mineral dan batubara dalam perekonomian Provinsi Banten tahun 2000 - 2025: Pendekatan antar industri," JTM, XIX(3).

Subanti, S. and Hakim, A. R. (2009) "Ekonomi regional Provinsi Sulawesi Tenggara: Pendekatan sektor basis dan analisis input -output," Jurnal Ekonomi dan Studi Pembangunan, 10(1), pp. 13-33. Available at:

https://media.neliti.com/media/publications/3 0669-ID-ekonomi-regional-provinsi-sulawesi- tenggara-pendekatan-sektor-basis-dananalisis.pdf.

Subanti, S. and Hakim, A. R. (2015) Peran Sektor Ekonomi Prioritas Terhadap Kesempatan Kerja dan Pendapatan di Indonesia Tahun 1995-2005 (Analisis Input-Output). Available at:

https://www.researchgate.net/publication/288 591993_Peran_Sektor_Ekonomi_Prioritas_Ter hadap_Kesempatan_Kerja_dan_Pendapatan_d i Indonesia Tahun 1995 2005_Analisis_Input-Output.

Sumardjoko, I. (2013) Analisis pengaruh transfer ke daerah terhadap pertumbuhan ekonomi Regional Papua sebagai upaya penguatan desentralisasi asimetri. Universitas Airlangga.

Tounsi, S., Ezzahid, E., El Alaoui, A. and Nihou, A. (2013) "Key sectors in the Moroccan economy: An application of input-output analysis," Economics: The Open-Access, Open-Assessment E-Journal, 7(2013-18), p. 1. doi: 10.5018/economics-ejournal.ja.201318.

Weisbrod, G. (2017) Economic impact tools and models: are they useful?, EDR Group. Available http://www.edrgroup.com/blog/economicimpact-tools-and-models-are-they-useful.html (Accessed: March 1, 2016).

Weya, O., Naukoko, A. T. and Kawung, G. M. (2015) "Analisis pertumbuhaan ekonomi dan pendapatan asli daerah \& PDRB di Provinsi Papua," Jurnal Berkala Ilmiah Efisiensi, 15(5), pp. 59-65. Available at: https://ejournal.unsrat.ac.id/index.php/jbie/art icle/view/9695. 